\title{
RELIGIŌES AFRO-BRASILEIRAS: RIVALIDADE E FRACASSO ELEITORAL
}

\author{
Andréa Grazziani Otero ${ }^{1}$ \\ Cintia Aguiar de Avila \\ Rosilene dos Santos Schoenfelder ${ }^{3}$
}

Resumo: $\mathrm{O}$ presente artigo visa analisar a participação de candidatos sacerdotes das religiōes afro-brasileiras nas eleições para vereador na cidade de Porto Alegre no ano de 2004. A partir desta análise será discutida a relação entre o fracasso eleitoral dos mesmos e a rivalidade existente entre as suas estruturas de apoio.

Palavras-chave: Religiões afro-brasileiras, Rio Grande do Sul, eleições 2004

Keywords: Afro-Brazilian Religions, Rio Grande do Sul, elections 2004

É cada vez mais comum candidatos a determinado cargo político, em sua campanha eleitoral, fazerem o uso de suas identidades sociais. Com isto, buscam a familiarização dos eleitoresatravés dessa identidadee, conseqüentemente, seu voto. Nesta última eleição para o legislativo em Porto Alegre foi observadoinúmeros candidatosque utilizaramsuas identidades profissionais, religiosa ou até mesmo de sua identidade sexual para conquistar o eleitor.

No presente artigo, será analisada a participação de candidatos que utilizaram suas identidades religiosas, mais especificamente dos candidatos a vereador afro-religiosos. Nesta última eleição houve três candidatos a vereador que pertencem a este segmento religioso. Tais candidatos eram: Jorge Verardi, Vera Soares e Angel de Oxum.

${ }^{1}$ Licenciada em Ciências Sociais na UFRGS e bolsista PIBIC/CNPQ do Núcleo de Estudos da Religião (NER).

2 Estudante de graduação do Curso de Ciências Sociais da UFRGS e bolsista BIC/ PROPESQ/UFRGS, do Núcleo de Estudos da Religião (NER).

${ }^{3}$ Aluna visitante de graduação do Curso de Ciências Sociais da UFRGS e bolsista voluntária do Núcleo de Estudos da Religiáo (NER).

Debates do NER, Porto Alegre, ano 5, N. 6, p. 129-148, dezembro 2004 
Jorge Verardi, babalorixá, ${ }^{4}$ era candidato pelo PDT (Partido Democrático Trabalhista). Cabe salientar que não é a primeira vez que Verardi candidatou-se a um cargo político, concorreu a deputado estadual em 1990 e a vereador no ano de 2000, porém nunca conseguiu eleger-se. Verardi é formado em veterinária, tem trinta e quatro anos de religião e um grande terreiro no bairro Ipanema, zona sul de Porto Alegre. Ainda, é o presidente da federação AFROBRAS. ${ }^{5}$

Vera Soares, ialorixá, ${ }^{6}$ era candidata pelo PT (Partido dos Trabalhadores), tentava pela primeira vez se eleger a um cargo político. Vera é militante do Movimento Negro e faz parte de uma secretaria de promoção da igualdade social criada pelo governo Lula. Tem 57 anos, 40 dentro da religião afro e um terreiro há 25 anos.

Angel de Oxum, babalorixá, ex-músico, enfermeiro, delegado especial de proteção aos animais e ao meio ambiente, candidato pelo PSB (Partido Socialista Brasileiro), também se lança a um cargo político pela primeira vez. Tem 68 anos, 54 dentro da religião afro e é dono de um terreiro há 44 anos.

Aumenta cada vez mais o discurso, junto a este segmento religioso, de que a tentativa de sua inserção política se vincula à defesa da sua religião frente aos ataques que lhe são desfechados pela Igreja Universal do Reino de Deus (IURD). De fato, esta igreja neopentecostal vem movendo ataques $^{7}$ aos afro-religiosos em seus cultos, em programas de televisão, rádio, jornais, dispóe de ampla bibliografia disseminada nos templos e livrarias

\footnotetext{
${ }^{4}$ Nome pelo qual é designado o sacerdote do sexo masculino, nas religiōes afro-brasileiras. Também é chamado de pai-de-santo.

${ }^{5}$ A AFROBRAS é a maior e mais conhecida federação dos cultos afro-brasileiros do Rio Grande do Sul, contando com cerca de 40.000 terreiros associados.

${ }^{6}$ Nome pelo qual é designada a sacerdotisa nas religiōes afro-brasileiras. Também é chamada de mãe-de-santo.

${ }^{7}$ Segundo a IURD, o demônio é o causador de todos os males que afligem a sociedade. Males como: doenças, desemprego, vícios, separação de casais, até mesmo impotência, frigidez e obesidade. Mas o que chama a atenção é o fato de que os demônios causadores de tais males são as entidades cultuadas nas religiões afro-brasileiras, tratadas pela IURD pelo nome genérico de "encostos". Ver Oro, Ari Pedro, 1997.
} 
evangélicas (como por exemplo o livro "Orixás, Caboclos e Guias - Deuses ou Demônios?”, escrito por Edir Macedo, fundador da IURD), entre outros meios de comunicação utilizados. Enfim, a IURD fez uma demonização do panteão afro-religioso e atua em seus templos com o objetivo de exorcizálos, declar an do a chamada "Guerra Santa".

Os membros das religióes afro-brasileiras vêem a IURD como um segmento religioso extremamente intolerante e racista, que vê o demônio em toda manifestação cultural africana, e não somente na religião, fechado à troca de idéias com outras religióes, como se fosse uma revivicência do que foi a perseguição aos cultos afro feita pela Igreja Católica, juntamente com a polícia e o Estado no passado.

O procedimento metodológico adotado para a busca de informações consistiu na coleta e análise de material de campanha impresso (panfletos, cartazes, adesivos, etc.), bem como na gravação e análise da propaganda eleitoral veiculada na televisão.Foram feitas também quatro entrevistassemidiretivas: com os três candidatos mencionados acima e com Marco de Bará Lanã, diretor de fiscalização da AFROBRAS e colaborador da campanha de Jorge Verardi. Ainda foram feitas observações participantes nas reuniōes da Comissão em Defesa das Religiões Afro-Brasileiras (CDRAB). ${ }^{8}$ Para esta análise foram levados em consideração aspectos lingüísticos (escritos, orais) e não lingüísticos (iconográficos), como a apresentação pessoal dos candidatos no vídeo, assim como os símbolos e imagens utilizadas.

A identificação de tais candidatos ${ }^{9}$ se deu pelo fato de evidenciarem sua identidade religiosa. Os critérios utilizados para identificação dos candidatos sacerdotes foram o uso da indumentária religiosa e/ou uso do nome "de religião". ${ }^{10}$ Observamos que os candidatos Jorge Verardi e Vera Soares

${ }^{8} \mathrm{O}$ tema CDRAB será objeto de análise mais à frente.

${ }^{9}$ Outro candidato afro religioso foi identificado nestas eleições de 2004 para o legislativo, mas não será objeto de estudo neste artigo, pois não evidenciou sua religiosidade durante a campanha.

${ }^{10}$ Convencionou-se no Rio Grande do Sul, no meio afro-religioso, chamar alguém como sendo "de religião" quando pertencente a qualquer religião de matriz africana (umbandistas, batuqueiros, linha cruzada, etc). 
não utilizaram o nome de seu orixá para designá-los: Jorge de Xangô ou Vera de Iansã, mas sim seus sobrenomes Verardi e Soares. Já Angel, utilizou o nome de seu orixá protetor Oxum. A identidade religiosa de Vera Soares e Jorge Verardi aparece principalmente pelo uso da indumentária afro-religiosa. Outra característica de identidade religiosa aparece no discurso dos candidatos seja no material publicitário e/ou na propaganda eleitoral veiculada na televisão.

\section{ANÁLISE DA PROPAGANDA POLÍTICA E DO MATERIAL DE CAMPANHA DOS CANDIDATOS:}

\section{NA TELEVISÃO}

Para a coleta de informações que constitui um dos eixos deste trabalho foram gravados e analisados dez programas eleitorais. ${ }^{11}$ que tornaram possível a observação da apresentação e discurso usado na campanha eleitoral transmitida pela televisão.

A propaganda política de Jorge Verardi foi poucas vezes veiculada na televisão e tinha curta duração. Jorge Verardi apare cia vestido com indumentária religiosa, na cor branca, usando um filá (chapéu africano) e uma guia imperial, que é a guia usada pelos babalorixás. Ao fundo ouvia-se o som de tambores. Em sua fala enfatizava a necessidade de "dar um basta nos candidatos pára-quedistas", isto é, que caem de pára-quedas nos terreiros em época de eleiçôes. Vera Soares, por sua vez, teve a propaganda eleitoral veiculada mais vezes na televisão do que Jorge Verardi e com um tempo de

\footnotetext{
${ }^{11}$ A propaganda eleitoral na televisão teve seu início em 17 de agosto e término em 30 de setembro de 2004 conforme a resolução número 21610 do Tribunal Superior Eleitoral (TSE). Era transmitida em dois horários distintos: das 13 horas e às 20:30, tinha duração de trinta minutos. A apresentação dos programas eleitorais era intercalada, sendo um dia para a campanha dos candidatos à prefeitura e outro para a campanha dos candidatos a vereador.
} 
fala maior do que o dos outros dois candidatos. Aparecia vestida de axó branco (indumentária religiosa usada pelas mulheres de religião africana), trunfa e guia vermelha e branca (relacionadas tanto com seu orixá Iansã, quanto com as cores do seu partido). Eis sua fala na propaganda eleitoral:

"Com Raul Pont e Maria do Rosário busco respeito na diversidade, nas intolerancias. Na busca do equilíbrio e reintegração do homem com seus maiores valores, a vida e sua identidade., Vera Soares, 13.713. Afirmo que um mundo com tolerância é possivel'.

Assim como Vera Soares, a propaganda eleitoral de Angel de Oxum foi veiculada mais vezes na mídia do que a de Verardi, porém esta também era de curtaduração. O candidato aparedia vestido com roupasnão religiosas,camiseta branca com uma camisa azul marinho por cima, corrente no pescoço (não guias). Eis a fala do candidato Angel de Oxum na propaganda eleitoral: "Você, vamos mudar. Chega de promess e preconceitos, vote Angelde Oxum, 40032".

Nenhum dos candidatos explicitou a sua religiosidade no seu discurso na campanha para a televisão. Provavelmente isto se deva ao fato de desejarem atingir outros eleitores, não necessariamente praticantes da religião afro. Jorge Verardi e Vera Soares deixaram transparecer tais características pelo uso da indumentária religiosa ou pela própria música de fundo.

\section{NO MATERIAL IMPRESSO}

No material impresso de Jorge Verardi havia o slogan: "Porto Alegre com muito axê". Assim como na televisão, na foto do seu material usava a indumentária religiosa. Ao lado da fotografia dele aparecia a estátua do Orixá Oxum (tida, segundo a cosmovisao afro-religiosa, como sendo a dona das águas doces, identificada com o Rio Guaíba e tida como a protetora de Porto Alegre). ${ }^{12}$ Também Vera Soares, em seu material impresso, estava ves-

12 Esta estátua está situada próximo à praia de Ipanema em Porto Alegre. 
tida com a mesma roupa da televisão. Seu slogan era: "uma ação afirmati$v a$ ", uma expressão freqüentemente utilizada no movimento do qual faz parte, o Movimento Negro. Já Angel de Oxum, em seu material impresso, usava o slogan "União de todas as religioes", onde apresenta também algumas de suas propostas: lutar em prol da religião afro, lutar pelo bem estar social, lutar por maior proteção ambiental e ajudar a classe operária. Assim como na propaganda eleitoral transmitida na televisão não usou a indumentária religiosa. $\mathrm{Na}$ foto do material publicitário pode-se perceber o uso de guias.

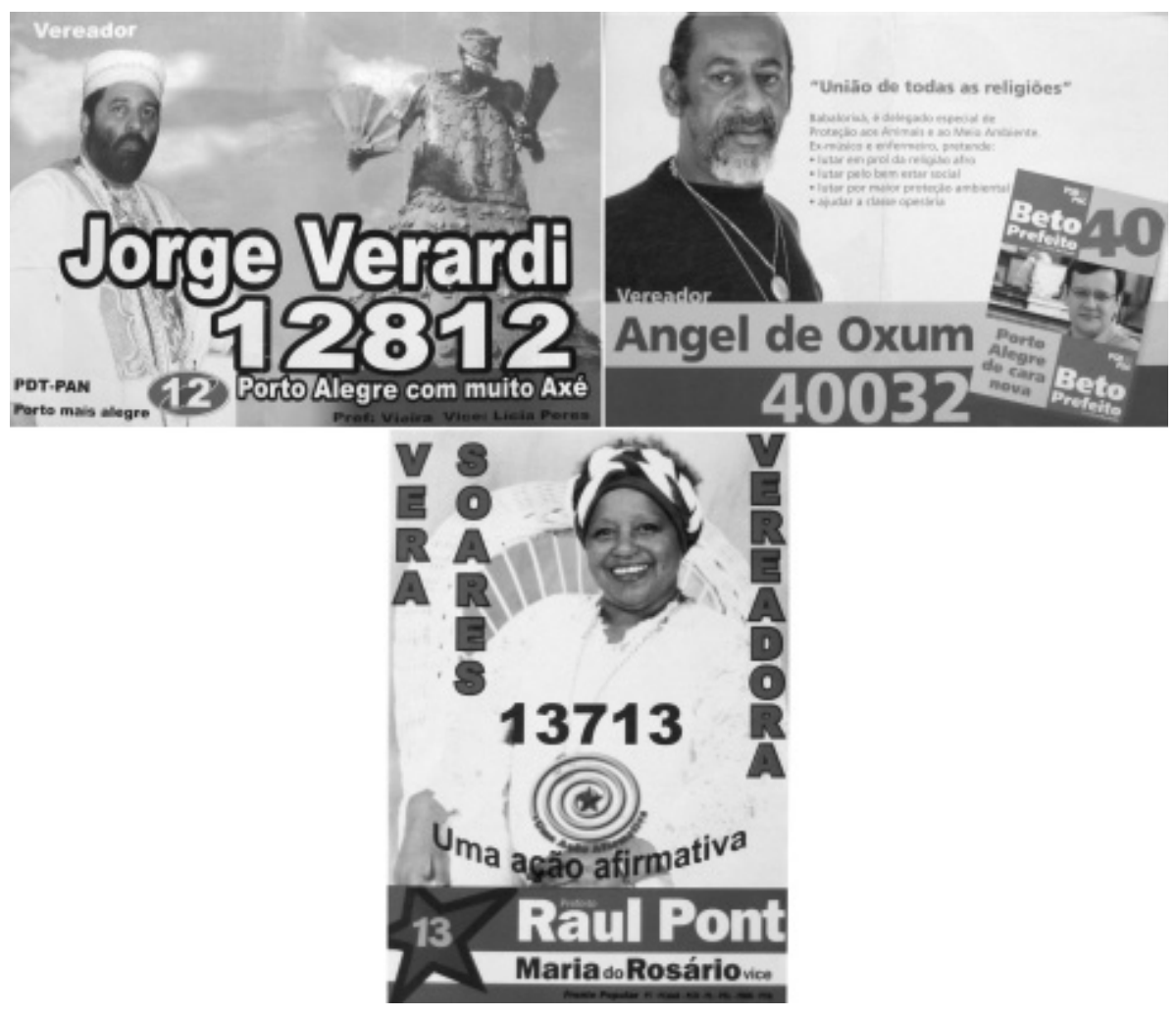

Debates do NER, Porto Alegre, ano 5, n. 6, p. 129-148, dezembro 2004 
Jorge Verardi e Vera Soares possuíam um material impresso específico direcionado ao público "de religião". Jorge Verardi em sua "carta aos irmãos" enfatiza a crítica aos evan gélicos que possuem represen tan tes no parlamen to e com isso pretend em "minar" a liberdade religiosa afro. Propunha "lotar de branco" a câmara dos vereadores, referindo-se à rou pa branca dos afro-religiosos. Vera Soares, em sua "Carta à Comunidade Terreira de Matriz Africana”, enfatiza a questão da mulher, da igualdade racial, da reintegração do homem com o meio ambiente, da inclusão social, bem como o comprometimento com os terreiros de matriz africana.

\section{NA INTERNET}

Observou-se principalmente nesta campanha eleitoral de 2004 o uso da Internet para fazer campanha. Muitos candidatos possuíam seus próprios sites. Outros disponibilizavam seus e-mails para sugestões, críticas, etc. Ou mandavam e-mails no intuito de uma maior obtenção de votos. Porém, entre os candidatos "de religião", somente dois fizeram uso da internet: Jorge Verardi disponibilizou seu e-mail em seu material publicitário e Vera Soares possuía um site na Internet, que ficou no ar somente na época da campanha. Quando interrogada sobre o uso da internet para obtenção de votos Vera replicou:

"Eu tenho um olhar de ialorixá e uma experiência de lidar com o ser humano. Não tenho nada contra as pessoas que façam o modê, tem modernos, bem caras as suas propagandas, mas eu ainda quero dizer que o eleitor, eu sempre defendo que o eleitor tem que ter a liberdade de voto, né, um direito humano, né, para não falar em democrático, um direito humano da pessoa olhar a pessoa, de sentir a pessoa e dizer "eu vou votar por isso, por isso", que eu chamo de voto consciente. Então, não sei se eu tivesse condiçôes se eu faria isso, acho que seria incoerente com os meus princípios. Eu gosto e quero ser eleita sim, mas quero ser votada com o voto consciente".

A partir da análise da propagada política na televisão, material impres- 
so e na internet, podemos traçar um perfil comparativo dos candidatos "de religião". Pode-se observar que os candidatos deixam clara sua religiosidade tanto pelo uso do nome de Orixá quanto pelo uso da indumentária religiosa. Os três candidatos não fizeram uso de terminologia afro-religiosa em seus discursos na propaganda eleitoral veiculado na televisão, mas em compensação dois deles, Verardi e Vera Soares, possuem material impresso específico dirigido ao público afro, demonstrando não só o perfil dos candidatos, mas também o perfil do público alvo de suas campanhas. Quanto à divulgação da campanha eleitoral, os três candidatos dispuseram de pouco tempo na propaganda eleito ral (Verardi e Angel apareciam no víd eo aproximadamente durante oito segundos) sendo que Vera é quem dispunha de maior tempo no ar (um minuto). Verardi e Vera fizeram uso de propaganda virtual, o primeiro disponibilizando seu e-mail no material impresso onde aceitava críticas e sugestôes para sua campanha; a segunda possuía site em construção. ${ }^{13}$

\section{ANÁLISE DAS ENTREVISTAS}

Durante a realização das entrevistas, buscou-se captar junto às três candidaturas apresentadas a motivação e os objetivos para concorrer a vereador, suas expectativas com relação às eleições, as estratégias utilizadas para obtenção de votos, de quem estavam obtendo apoio, como estavam encarando a concorrência com os demais candidatos afro-religiosos e de outros segmentosreligiosos, se possuíam alguma assessoriaprofissional (marketing), as pessoas e instituições que estavam sendo mobilizadas em sua campanha, no caso de serem eleitos se deixariam as suas atividades como babalorixás e, por fim, como esses candidatos vêem a relação entre religião e política.

As perguntas do questionário de entrevista foram lidas previamente para os três candidatos. As entrevistas se realizaram no comitê dos candidatos, no caso de Verardi e Vera, e no Núcleo de Estudos da Religião na

\footnotetext{
${ }^{13}$ Ao menos até a última data de visita ao site pelas pesquisadoras, 20 de setembro de 2004.
} 
UFRGS com Angel. Verardi não usou indumentária religiosa na entrevista, Vera usava uma vestimenta que lembrava trajes africanos e Angel estava vestindo roupa branca e usava guias no pescoço. A seguir analisaremos o discurso de cada um dos três candidatos e a análise será ilustrada num quadro comparativo.

Quanto à motivação e os objetivos da campanha, Verardi disse que pretendia defender a religiāo africana, principalmente do ataque dos evangélicos e garantir a liberdade religiosa. Também alegou que muitos irmãos de religiāo vinham o pressionando para candidatar-se. Para Angel, sua maior motivação é ajudar os mais necessitados, os aidéticos. Sua maior preocupação era com os problemas sociais, que, segundo ele, seriam resolvidos com a doação de cadeiras de rodas, óculos, calçados, remédios, evidenciando um assistencialismo em seu discurso. Também desejava combater os ataques dos evangélicos, mas essa não era a sua maior prioridade. Vera, há 25 anos quando se "aprontou" na religião, também começou a participar do Movimento Negro, enquanto espaço de discussão e formação de políticas em busca da promoção da igualdade, da inclusão social. Assim, diz, a política entrou em sua vida.

Quanto às expectativas dos candidatos, Verardi esperava receber votos de membros da religião africana, mesmo tendo consciência da desunião existente neste meio religioso. Por isso, buscou um reforço externo de outros segmentos não religiosos, como a maçonaria, por exemplo, da qual é integrante. Segundo ele, os afro umbandistas não têem unidade. Mas, ao mesmo tempo em que enfatizava a desunião no meio afro-religioso possuía grande expectativa de vencer. Pronunciou frases como: "desta vez eu acredito, sim, que nós vamos conseguir"; "a gente sente no corpo a corpo"; "nossos irmãos estão apoiando". Angel esperava receber votos das pessoas que o conhecem, dos amigos, sendo que $70 \%$ seriam da religião e $30 \%$ da comunidade onde vive. Assim como Verardi, Angel também demonstrou ter consciência da desunião existente no meio afro-religioso. Vera tinha a expectativa de que a comunidade negra tivesse a consciência de votar no negro. Desejava defender a religião africana, principalmente das críticas dos Pentecostais, a liberdadede culto. Segundo ela, é necessário haver babalorixás 
e ialorixás nos espaços de decisão, para ajudar a resgatar a identidade do negro e buscar a igualdade social.

No que se refere às estratégias de campanha dos candidatos, Verardi contou com importan te material impresso: cartas, panfletos, cartazes, banners, faixas. Quinhentos mil santinhos foram entregues em mãos nos terreiros. A sua campanha foi feita no corpo a corpo. Possuía seis equipes que colaboravam com ele. $\mathrm{O}$ candidato chegava a visitar de seis a oito festas religiosas numa noite. Visitou mais de dois mil terreiros. Já Angel, no que se refere ao material impresso, foram confeccionados 30.000 panfletos, doados pelo partido (PSB), e 25.000 "colinhas" (panfleto explicativo com o número do candidato). Porém, o candidato mandou confeccionar mais 5.000 por conta própria. Angel lamentou a falta de ajuda financeira na sua campanha, sobretudo do partido. Pediu dinheiro nas casas de religião mais ricas.Visitou centenasde terreiros. Não utilizoua estratégiade colocarpanfletos em caixas de correios, pois, de acordo com ele, "as pessoas póem fora mesmo". Quanto à receptividade de outros babalorixás durante suas visitas aos terreiros, afirma ter sido ótima. Vera assumiu em seu material de campanha que é ialorixá para provar que não possui vergonha de sua religião. Não fez muito material gráfico, pois disse ser muito caro. A campanha exige muito dinheiro, e o Movimento Negro e o religioso não têm condições de financiar uma candidatura cara. A campanha foi feita no corpo a corpo, fazendo visitas, indo a seminários, reuniōes.

Quan to ao apoio e à concorrência dos outros candidatos "de religiāo", Verardi afirmou que não teve problemas. Via-se como o candidato de maior visibilidade no campo afro-religioso. Conhecia os demais candidatos, Angel e Vera. Disse que não os via como concorrentes, embora encarasse a concorrência como algo positivo. Já Angel disse possuir o apoio dos mais antigos na religião, que precisam dele, dos seus filhos, netos-de-santo e amigos. Angel via como seus verdadeiros concorrentes os candidatos do próprio partido (PSB). Para ele, entre os religiosos não deve haver disputa. Por isso, Jorge Verardi e Vera Soares não eram vistos como adversários. Angel disse não ter pedido votos apenas para si, mas também para os candidatos afro-religiosos. Para Vera, apoiaram na sua candidatura: seus filhos- 
de-santo, seus amigos do Movimento Negro, seus companheiros. Vera disse ter conversado com a CDRAB e com o seu próprio terreiro, que construiu o Conselho Nacional de Ialorixás e Ekedes Negras.

Quanto à concorrência de candidatos de outras religióes, de acordo com Verardi, nenhuma religião deveria estar contra a outra. Algumas pentecostais é que se colocam contra os afro-religiosos acusando-os de pessoas do mal. Referiu-se àquelas religióes dizendo ter piedade dos mesmos, pois estes querem conquistar a fatia da sociedade antes pertencente ao segmento afro, ou seja, a população mais pobre. Já Angel disse que só no seu partido, PSB tinha uns 20 candidatos evangélicos, mas que não se declaravam como tais. Vera conhece candidatos de outras religióes, pois dentro do seu partido (PT), existe a coligação com o PL, partido onde há candidatos pastores evangélicos. Disse não ter convivência com eles, mas os conhece. Afirmou que, com certeza seriam eleitos, até porque a Igreja possui uma organização e estrutura financeira maior.

Os três candidatos afirma m não ter tido uma assess oria profissional. Verardi contava com a prática em campanhas políticas anteriores. Disse não possuir dinheiro para contratar um marketing político. Seus cabos eleitor ais eram seus próprio s filhos- de-santo, que trabalha ram gratuitam ente na sua campan ha. Angel disse que andava sozinh o, a pé, não tendo verbas nem para o combustível dos automóveis que conseguiu emprestado com amigos. Ficou com seis carros parados em frente a sua casa sem poder utilizá-los. Confessou que precis ou vender até o telefone celular para bancar sua campanha. Havia cinco rapazes que faziam campanha gratui tamente para ele. Vera também não possuía assess oria técnica, mas tinha uma filha-de-sa nto que é socióloga e que contribuiu bastan te na articulação política. Também havia militantes trabal hando com material gráfico.

Quanto às pessoas e instituiçõ es mobilizadas na campanha dos candidatos, Verardi disse que contava com o apoio de algumas federaçóes, como, por exemplo, o CEUCAB (Conselho Estadual da Umbanda e dos Cultos Afro-Brasileiros). Angel disse não ter tido apoio de ninguém, enquanto que Vera afirmou que tinha o apoio de vários grupos do Movi- 
mento Negro. Ela faz parte da Coordenação do Fórum Estadual de Entidades Negras, vinculada à Coordenação Nacional das Entidades Negras (CONEN). Segundo ela, 70\% das entidades estavam trabalhand o na sua campanha: a Coordenadoria Executiva de Cooperação Universitária de Atividades Especiais (CECAE), o jornal Afro Conesul, a CDRAB, associações e terreiros que não são vinculados a nenhuma associação. Contava também com a mobilização de entidades carnavalescas e entidades de mulheres negras.

Ao serem interrogados sobre, se caso eleitos, deixariam a religião, todos foram unânimes em responder negativamente. Verardi disse que iria conciliar as duas atividades. Não seria um político/babalorixá, mas um babalorixá/político. Angel disse que em primeiro lugar vem a religião depois a política. Vera disse: "a vereadora Vera Soares vem depois da ialorixá Vera de Iansä". E indagou: "Uma mãe abandona um filho ? Então, eu não poderia jamais abandonar meus filhos-de -santo! O terreiro veio antes da candidatura". Se eleita jun taria a política e a religião.

Todos os candidatos vêem uma estreita relação entre religião e política. Para Verardi, não é possível viver sem política. O homem é um ser político: "temos que discutir, trocar idéias ver o que é melhor para a religiäo". Política deve andar junto com a religiāo, a fim de assegurar os direitos adquiridos, a liberdade religiosa. É importante ter representantes da religiäo, para não precisar implorar projetos para simpatizantes". Angel somente respondeu que a religião-afro não quer competir, não quer governar, mas quer um espaço. Para Vera Soares, as duas coisas não se separam: "Eu defendo que a religiāo seja ela qual for o segmento, cada ser humano segue um principio religioso, é uma politica sua. Eu digo que a religiāo não se separa da política individual de cada um como macro política, uma macro política dirigida". Vera não consegue ver a religiosidade, seja ela católica, pentecostal ou africanista, separada da política. Para ela, se não acreditarmos em nada, a vida torna-se vazia: "Eu não acredito no ateu, porque o ateu diz: Deus me livre de acreditar em Deus (risos). A política e a religiāo são duas coisas que identificam um ser humano, aquilo que ele acredita, são coisas iniciais, principais e nativas de um ser humano." 
Quadro I - Perfil dos candidatos na entrevista

\begin{tabular}{|c|c|c|c|}
\hline & Vera Soares $(\mathrm{PT})$ & $\begin{array}{l}\text { Angel de Oxum } \\
\text { (PSB) }\end{array}$ & $\begin{array}{l}\text { Jorge Verardi } \\
\text { (PDT) }\end{array}$ \\
\hline $\begin{array}{l}\text { Motivação/ } \\
\text { Objetivos }\end{array}$ & $\begin{array}{l}\text { Promoçáo da } \\
\text { igualdade, } \\
\text { Inclusão social. }\end{array}$ & $\begin{array}{l}\text { Ajudar os mais } \\
\text { necessitados. } \\
\text { Fundo Social. }\end{array}$ & $\begin{array}{l}\text { Defesa da religião, } \\
\text { liberdade } \\
\text { religiosa. }\end{array}$ \\
\hline Expectativas & $\begin{array}{l}\text { Confunde-se com } \\
\text { suas motivaçōes } \\
\text { e objetivos. } \\
\text { Implementar } \\
\text { propostas, } \\
\text { projetos-lei para } \\
\text { o povo negro. } \\
\text { Defender a } \\
\text { religião africana. }\end{array}$ & $\begin{array}{c}\text { Votos de } \\
\text { conhecidos, } \\
\text { amigos. } \\
\text { 70\% da religião, } \\
30 \% \\
\text { não religiosos }\end{array}$ & $\begin{array}{l}\text { Receber votos de } \\
\text { afro-religiosos } \\
\text { (apesar de serem } \\
\text { desunidos). }\end{array}$ \\
\hline Estratégias & $\begin{array}{l}\text { Não fez muito } \\
\text { material gráfico } \\
\text { por falta de } \\
\text { verbas. A } \\
\text { campanha foi } \\
\text { feita no corpo a } \\
\text { corpo, fazendo } \\
\text { visitas, indo a } \\
\text { seminários e } \\
\text { reunióes. }\end{array}$ & $\begin{array}{l}30 \text { mil panfletos } \\
\text { e } 25 \text { mil colinhas. } \\
\text { Visita de } 10 \text { a } 15 \\
\text { casas por dia (de } \\
\text { religião ou não). }\end{array}$ & $\begin{array}{c}500 \text { mil panfletos. } \\
\text { Visita a } 40 \\
\text { terreiros e cerca } \\
\text { de } 6 \text { a } 8 \text { festas } \\
\text { por noite. }\end{array}$ \\
\hline $\begin{array}{c}\text { Apoio } \\
\text { Concorrência }\end{array}$ & $\begin{array}{l}\text { Não falou sobre } \\
\text { concorrência. } \\
\text { Contou com o } \\
\text { apoio de seus } \\
\text { filhos-de-santo e } \\
\text { companheiros do } \\
\text { Movimento } \\
\text { Negro }\end{array}$ & $\begin{array}{c}\text { Via como } \\
\text { concorrentes } \\
\text { os candidatos } \\
\text { do próprio } \\
\text { partido (PSB), } \\
\text { não Vera Soares } \\
\text { e Jorge Verardi. }\end{array}$ & $\begin{array}{l}\text { Via-se como } \\
\text { o candidato } \\
\text { de maior } \\
\text { visibilidade. } \\
\text { Conhecia os } \\
\text { demais, mas não } \\
\text { os considerava } \\
\text { concorrentes. }\end{array}$ \\
\hline
\end{tabular}

(cont.) 
(cont.)

\begin{tabular}{|c|c|c|c|}
\hline $\begin{array}{l}\text { Assessoria } \\
\text { Profissional }\end{array}$ & $\begin{array}{c}\text { Não possuía. } \\
\text { Contou com a } \\
\text { contribuição de } \\
\text { uma socióloga e } \\
\text { de militantes do } \\
\text { Movimento } \\
\text { Negro. }\end{array}$ & $\begin{array}{l}\text { Não tinha. } \\
\text { O partido } \\
\text { não o apoiou. }\end{array}$ & $\begin{array}{c}\text { Não tinha. Usava } \\
\text { a sua experiência } \\
\text { em campanhas } \\
\text { políticas } \\
\text { anteriores. }\end{array}$ \\
\hline $\begin{array}{l}\text { Concorrência } \\
\text { com outras } \\
\text { religióes }\end{array}$ & $\begin{array}{c}\text { Conhece } \\
\text { os candidatos } \\
\text { evangélicos } \\
\text { do PL. Tinha } \\
\text { certeza que estes } \\
\text { seriam eleitos, } \\
\text { pela organização } \\
\text { e estrutura } \\
\text { financeira } \\
\text { da igreja. }\end{array}$ & $\begin{array}{l}\text { Conhece só no } \\
\text { seu partido, uns } \\
20 \text { candidatos } \\
\text { evangélicos, } \\
\text { mas que não se } \\
\text { declaravam } \\
\text { como tal. }\end{array}$ & $\begin{array}{c}\text { Nenhuma religião } \\
\text { deveria estar } \\
\text { contra a outra. } \\
\text { Tem piedade dos } \\
\text { evangélicos que } \\
\text { querem a custa } \\
\text { de mentiras } \\
\text { conquistar os } \\
\text { mais pobres. }\end{array}$ \\
\hline $\begin{array}{l}\text { Pessoas e } \\
\text { instituições } \\
\text { mobilizadas }\end{array}$ & $\begin{array}{c}\text { Movimento } \\
\text { Negro. } \\
\text { Associaçóes } \\
\text { e jornais afro. } \\
\text { Terreiros, } \\
\text { entidades } \\
\text { carnavalescas } \\
\text { e entidades de } \\
\text { mulheres negras. }\end{array}$ & $\begin{array}{l}\text { Não teve apoio de } \\
\text { quase ninguém. }\end{array}$ & $\begin{array}{l}\text { Filhos-de-santo, } \\
\text { que trabalharam } \\
\text { gratuitamente. }\end{array}$ \\
\hline $\begin{array}{l}\text { Deixaria a religião } \\
\text { caso fosse eleito? }\end{array}$ & $\begin{array}{c}\text { Jamais } \\
\text { abandonaria } \\
\text { a religião. } \\
\text { "Uma mãe não } \\
\text { abandona seus } \\
\text { filhos". }\end{array}$ & $\begin{array}{c}\text { Não. Em } \\
\text { primeiro lugar } \\
\text { a religiāo, } \\
\text { depois a política. }\end{array}$ & $\begin{array}{c}\text { Não. Procuraria } \\
\text { conciliar a duas } \\
\text { coisas. Seria um } \\
\text { babalorixál } \\
\text { político. }\end{array}$ \\
\hline $\begin{array}{c}\text { Relação Religião e } \\
\text { Política }\end{array}$ & $\begin{array}{c}\text { São duas coisas } \\
\text { que não se } \\
\text { separam, iniciais, } \\
\text { principais e } \\
\text { nativas do ser } \\
\text { humano. } \\
\end{array}$ & $\begin{array}{l}\text { A religião não } \\
\text { quer governar, } \\
\text { mas quer um } \\
\text { espaço. }\end{array}$ & $\begin{array}{l}\text { Deve existir. Para } \\
\text { discutir, tratar, } \\
\text { trocar idéias sobre } \\
\text { o que é melhor } \\
\text { para a religiāo. }\end{array}$ \\
\hline
\end{tabular}

Debates do NER, Porto Alegre, ano 5, N. 6, P. 129-148, DeZembro 2004 
Verardi poucas vezes se referiu aos orixás e aos fundamentos religiosos durante a entrevista, detendo-se apenas nas questôes políticas. Estava bastante confiante na vitória usando sua experiência como presidente da federação AFROBRAS para legitimar sua capacidade de representar os religiosos africanistas. Durante toda a entrevista afirmou ter planos maiores para a religião. Angel pareceu gostar falar mais sobre a religião do que sobre política. Mostrou-se cansado, endividado e, até mesmo, arrependido de candidatar-se. Seu desejo era ajudar os mais próximos, amigos, vizinhos, pessoas necessitadas, caso fosse eleito. Ao mesmo tempo em que demonstrava esperança em eleger-se, demonstrava também desilusão, principalmente com o próprio partido (PSB), que não deu o apoio necessário. Pessoas filiadas ao PSB foram a sua casa e o convenceram a candidatar-se. Angel afirmou não gostar de política, nem de políticos. Chegou a dizer: "Para o pobre e para o negro tudo é ilusão". Vera como militante do Movimento Negro, muitas vezes referiu-se mais a questão do negro, do que da religião africana em si. Fez questão de apresentar-se:

"Eu sou Vera Soares. Sou Vera e o nome religioso é Vera de Iansã, ou melhor, Vera de Oiá Lajá, que vem do povo de Keto, cultua a nação Oió. Fui pronta, fui filha Ivo de Ogum Onira, que é responsável pela minha tina. ${ }^{14}$ Tenho um terreiro, Centro Memorial de Matriz Africana Treze de Agosto, há vinte cinco anos. E sou conhecida publicamente como mãe-de-santo, já com vários filhos de santo".

Após o processo eleitoral, os três candidatos, Jorge Verardi, Angel de Oxum e Vera Soares, foram procurados novamente e indagados sobre o resultado das eleições, ou melhor, sobre o número de votos que obtiveram, insuficientespara serem eleitos vereadoresna Câmara de Vereadores de Porto Alegre. Jorge Verardi obteve 2.014 votos, Angel de Oxum obteve 93 votos e Vera Soares obteve 623 votos. Portanto, nenhum deles obteve êxito elei-

\footnotetext{
${ }^{14}$ Quando Vera refere-se à Ivo de Ogum Onira como o responsável por sua tina, a candidata quis dizer que este babalorixá foi quem a iniciou na religião de matriz africana.
} 
toral. Tal fracasso eleitoral já era esperado por estes candidatos ou eles foram tomados de surpresa?

\section{ANÁLISE DO RESULTADO DAS ELEIÇŌES SEGUNDO OS PRÓPRIOS CANDIDATOS}

O candidato JorgeVerardi afirmou que esperava obter um número maior de votos, após ter feito uma exaustiva campanha e obtido grande receptividade nos terreiros visitados. Esperava ser eleito, apesar de ter a consciência de que o "povo afro-umbandista" é desunido. Afirmou que os afroreligiososainda não estão conscientesda necessidadede um representante seu ocupando cargos políticos. Ainda está avaliando, "amadurecendo a idéia", se irá candidatar-se novamente. Não descartou a possibilidade de se candidatar nas próximas eleiçóes para deputado estadual. Neste caso, pensa procurar outros segmentos além dos afros para suprir os votos não alcançados. Acredita que o interior do estado é mais fiel na hora de votar. Citou Moab Caldas, o único umbandista eleito até hoje como deputado estadual no Rio Grande do Sul, em 1964, e reeleito em 1968. Tal fato é visto por Verardi como uma prova da fidelidade do eleitorado do interior. Enfim, apesar de mais essa derrota, Jorge Verardi disse que irá persistir na política, principalmente porque gran de parte do seu "povo", isto é, seus filhos-de-santo, desejam que ele não desista de seu objetivo: eleger um representante afro-religioso para integrar a Câmara de Vereadores ou a Assembléia Legislativa.

Vera Soares disse que sendo esta a primeira vez que disputa um cargo político, esta vai servir de experiência para uma outra vez, insinuando que pretende se lançar novamente a uma próxima eleição. Ao contrário dos seus concorrentes, Vera Soares não justificou a falta de votos pela desunião na religião. Atribuiu o fracasso eleitoral ao seu partido, o PT, que após 16 anos na administração da cidade perdeu para o PPS (Partido Popular Socialista), transferindo a explicação do seu resultado da esfera religiosa para a esfera política. Na sua visão, teria sido prejudicada por uma tendência anti-petista que contribuiu para o declínio do Partido dos Trabalhadores. 
Angelde Oxum enfatizou tantopontos negativos, quantopositivosna sua candidatura. Para ele, os pontos negativos foram seu baixo desempenho (ter feito apenas 93 votos), sendo que se considera uma pessoa conhedida no meio afro. Para explicar seu fracasso eleitoral mencionou a falta de união dentro da religião. No que se refere aos pontos positivos, comparou-se a dois candidatos que não fizeram nenhum voto, portanto para uma primeira experiência, seu desempenho não teria sido tão ruim. Pretende candidatar-se para deputado estadual no ano de 2006, pelo mesmo partido, se o mesmo o aceitar.

Após o resultado das eleições Municipais de Porto Alegre, além de ouvirmos a posição dos próprios candidatos a respeito do seu fracasso eleitoral, procuramos captar também o posicionamento de indivíduos pertencentes às religiōes afro-brasileiras, tanto mães/pais-de-santo, quanto filhos-de-santo, sobre tal fracasso. Para isto foram feitas observações participantes nas reuniôes da CDRAB, ${ }^{15}$ uma associação formada por membros das religiōes africanas, situada em uma sala do Mercado Público de Porto Alegre, fundada pela Ialorixá Norinha de Oxalá, onde há grande circulação de indivíduos desta religião, e do movimento negro em geral, e discussões sobre diversos temas relacionados com a causa afro descendente, inclusive a política.

\section{ANÁLISE DO RESULTADO DAS ELEIÇŌES SEGUNDO MEMBROS DAS RELIGIŌES AFRO-BRASILEIRAS}

Os afro-religiosos em seu discurso colocam que devem se unir, não criticar os terreiros de outrem e sim aceitar as diferenças, mas na prática isto não ocorre. Por exemplo, a relação entre a CDRAB e a AFROBRAS não é nada

\footnotetext{
${ }^{15}$ Através de um membro do Movimento Negro e militante político de um partido de esquerda, Jairo Pereira, passamos a ter contato com este grupo de ialorixás (mães-desanto) e babalorixás (pais-de-santo), que indignados com a intolerância religiosa promovida pela IURD, resolveram formar no ano de 2002, uma Comissão em Defesa das Religiōes Afro-Brasileiras (CDRAB). Este grupo encontra-se semanalmente para fazer reuniōes e promoveu desde a sua fundação quatro seminários, inclusive um nacional, onde o tema central é sempre a intolerância religiosa, sobretudo da IURD.
} 
pacífica. Até mesmo no que se referiu à lei $11.915^{16}$ de Proteção aos Animais houve divergências. A CDRAB deu grande importância aos problemas que poderiam ser causados para o sacrifício de animais nos terreiros.A princípio a importância dada pela AFROBRAS a essa lei era pequena, pois a mesma não atingiria os cultos afro-brasileiros, já que os animais não são sacrificados com sofrimento e sua carne é utilizada para o consumo da comunidade religiosa. As atitudes da CDRAB são vistas pela AFROBRAS como "alarde".

Para a comunidade afro-religiosa da CDRAB, a maioria das pessoas de religião não votaram nos candidatos oriundos deste meio porque já possuíam seus candidatos, com os quais tinham afinidade ideológico-partidárias. São militantes do PT, do PC do B, do PDT, que já há algum tempo tratam da questão do operário, dos desempregados, do negro, incluindo aí, os afroreligiosos. Também não votaram neles em razão da sua baixa visibilidade no meio afro-religioso, embora essa seja diferente de acordo com os candidatos.

De acordo com os depoimentos recolhidos, os afro-religiosos disseram não ter votado em nenhum candidato sacerdote por não se sentirem representados por eles. Chegaram a dizer que "Ainda não apareceu a pessoa certa" para representar a religião na política local.

Diante disso, a proposição do CDRAB é de trabalhar a consciência política dos afro-religiosos, não aceitando troca de favores (patriarcalismo, clientelismo) com candidatos afro-religiosos ou simpatizantes.

\footnotetext{
${ }^{16}$ A lei 11.915, em defesa dos animais, foi criada pelo Deputado estadual Manoel Maria (PTB), evangélico da Igreja do Evangelho Quadrangular, constando que seria proibido o sacrifício de an imais, exceto para a alimentação. O que causou "alvoroço" no meio afroreligioso, sobretudo entre os membros da CDRAB. No dia 29/06/2004 foi aprovada a emenda redigida pelo Deputado Edson Portilho (PT), explicitando que tal lei não se aplica às religiōes afro-brasileiras. A emenda é considerada uma conquista para os afroreligiosos, que compareceram em massa na Assembléia Legislativa no dia da votação da mesma.O sacrifício de animais nas religióes afro-brasileiras é fundamental, pois é no sangue (ax orô), que está con tida a "energia vital" (axé), utilizando-se das palavras de Mauss (1974), o mana. Força, ação, qualidade, estado e substância. Algo que não tem razão de ser fora do social e que impede a análise lógica., pois é da ordem do sentimento, da sensação, da crença, sendo perceptível só a quem partilha as representações. É o grau zero do simbolismo e das representaçôes.
} 


\section{CONSIDERAÇÕES FINAIS}

A partir do conflito existente no campo afro-religioso, exposto na análise do resultadodas eleiçôes, podemos observar que o modelo organizacional desse campo é formado por várias federações e vários terreiros autônomos, sendo que estes muitas vezes são rivais entre si, como se pôde observar na fala tanto dos candidatos sacerdotes, quanto dos afro-religiosos em geral.

Nas religiōes afro brasileiras existem inúmeras "casas de religião", cada uma delas tendo um pai ou mãe-de-santo. Hierarquicamente, não existe nesta estrutura uma pessoa superior aos pais e mães de santo, que concentre poder, como ocorre nas igrejas evangélicas ou católica, ou seja, não há uma única hierarquia religiosa, nenhum poder centralizador e aglutinador (Oro, 2000). A estrutura afro-religiosa não é hierárquico-eclesial, vertical.

Sendo assim, existe uma disputa entre os terreiros tanto no que se refere ao conhecimento acerca dos fundamentos religiosos quanto pela conquista da clientela, que os procura para a realização de trabalhos espirituais. ${ }^{17}$ Segundo Prandi (1991), o ethos das religiões africanas é de disputa, rivalidade, desqualificação do outro e o fato de não se unirem, se reflete na dificuldade para a eleição de candidatos deste segmento. As próprias características das religiōes afro-brasileiras: atendimento individualista, satisfação de demandas particulares, sem cultivar um projeto social mais amplo com implicações políticas, dificulta a eleição proveniente desse meio religioso.

\footnotetext{
${ }^{17}$ Entende-se por trabalhos espirituais oferendas feitas aos orixás (entidades cultuadas nas religiōes afro-brasileiras) que visam a solução de problemas financeiros, afetivos, familiares, entre outros.
} 


\section{REFERÊNCIAS}

BIRMAN, Patrícia. Cultos de possessão e pentecostalismo no Brasil: passagens. Religião e Sociedade, 17/1-2, 1996:90-109.

MAUSS, Marcel. Sociologia e Antropologia - Vol.I. São Paulo: Editora Pedagógica e Universitária Ltda. EDUSP - Editora da Universidade de São Paulo, 1974.

MONTERO, Paula. Da ordem a desordem a magia na Umbanda. São Paulo: Graal, 1985.

OLIVEIRA, Rosiane Maiato de. O Sagrado Profanado - Estudo acerca do confronto entre afro-religiosos e a IgrejaUniversal do Reino de Deus. Monografia de Conclusão Ciências Sociais, Porto Alegre, UFRGS, 2003.

ORO, Ari Pedro. Neopentecostais e afro-brasileiros: quem vencerá esta guerra? Debates do NER, ano 1, n. 1. Publicação do Núcleo de Estudos da Religião no Programa de Pós graduação em Antropologia Social, UFRGS, 1997.

ORO, Ari Pedro et allii. Religião e Eleições 2000 em Porto Alegre. Debates do NER, ano 2, n. 3. Publicação do Núcleo de Estudos da Religião no Programa de Pós-Graduação em Antropologia Social, UFRGS, 2001.

PRANDI, Reginaldo. Os Candomblés de São Paulo. São Paulo: HucitecEdusp, 1991.

VELHO, Yvonne Maggie Alves. Guerra de Orixá - Um Estudo de Ritual e Conflito. Rio de Janeiro: Zahar, 1977. 